慢性脑局所アナフィラキシー家鬼胛髓のビョリンエス テラーゼ活性值, 遊離アネノ窒素及び神経細 胞内ケトエノール顆粒に関する研究

\author{
第 1 '編 \\ 慢性脳局所フナフィラキシー家兔脳娟のヒョリンエステラーゼ \\ 活性值に関する研究 \\ （本研究は文部省科学研究貲の補助淿よる）
}

(本論文要旨は，第53回日本精神神経学会並びそ第65回岡山医学総会に発表）

岡山大学医学部第一 (陣内) 外科数室（指導：漣内数授）

副手畠山哲朗

〔昭和 31 年 3 月 3 日受稿〕

$\begin{array}{ll}\text { 第 } 1 \text { 章 } & \text { 緒言並に文献 } \\ \text { 第 } 2 \text { 章 } & \text { 実験材料並に実験方法 } \\ \text { 第 } 1 \text { 節 } & \text { 実験動物 } \\ \text { 第 } 2 \text { 節 } & \text { 感作抗原の作成法 } \\ \text { 第 } 3 \text { 節 } & \text { 感作方法 } \\ \text { 第 } 4 \text { 節 } & \text { 効果注射の方法 } \\ \text { 第 } 5 \text { 節 } & \text { 脳採取方法及び検索部位 } \\ \text { 第 } 6 \text { 節 } & \text { 実験手技 }\end{array}$

\section{第1章 槠言並に文献}

Victor Horsley ${ }^{1)}$ は古代人の頭蓋骨に, 明 らかに瘦鹰の治療目的によると考えられる開 脳空があるといつているが，廎間は特異な症。 摮発作によつて医学の歴史以前より知られて いた最す古い疾患の一つである。一方におい $\tau$, 近年脳生理学, 脳生化学, 脳外科, 脳波 等の目ざましい進步により，微細な点につい てまで精密にして熱心な研究が行われて括り， 研究問題として最も新らしい疾患の一つとも 考えられるのである．しかしこの癲間の本態 については，古来諸多の学説2)374)5)677/8)が発 表されてはきたがまだ満足すべき定説がない 現状である.

そのーつとして真性頕痜がアレルギー過程
次

第 3 章 赛験成績

第 1 節 正常家兔群

第 2 節 牛脳灰白質ホスファチッド加 牛血清群

第 3 節 $\alpha$ 型連鎖状球菌群

第 4 節 小 括

第 4 章 総括並飞考按

第 5 章 結 論

によつて著起されるのではないかという考兄 方が古くからあつた． 即ち頻間の特徽である 発作の反覆する点, 血行障碍が重要な関係を もつ点，また䝷癎家系にアレルギー性疾患， 例光に゙偏頭痛，気管支喘息，蕁㾁疹，枯草熱 等が多く見られる(3)10)11)12)(3) 点等より，アレ

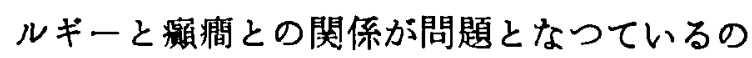
である。また種々の抗原と考えられるるのを るつて皮内反応を検すると，穎問患者飞陽性 率が高いといわれ14)，或はこれら抗原と考学 られるるのをさけ，或は脱感作を行うことに より痙㝈発作が軽快することがあるといわれ て打り(5)16)17)18)(9)20)，また特殊な食物を摄る ことにより発作を惹起する患者す報告されて

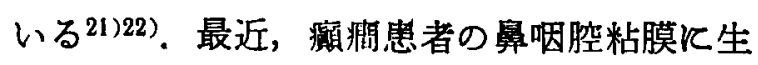
棲する $\boldsymbol{\alpha}$ 型連鎖状球菌を用いて皮内反忘を 
行 5 と，真性䝷間患者の 90 g6亿陽性であり (Rosenow) ${ }^{23)}$ ，ここれに基き Bering ${ }^{24)}$ は真性 瀕澗はその畄局所過敏症であろうといつてい る.

アレルギー説にしても他の多くの説にして も，痤攣発作の点火機序としては説明できる

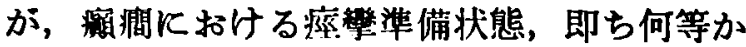
の点火機序により何故大脳全般飞爆発的神経 興副を誘発するかといつた本質的な準備状態 を説明することは困難である，真性頉間飞お。 ける嫣攣準備状態とは，脳に何ら器質的な変 化を認めえないに拘わらず，乙かす病攣に関 与寸る脳神経細胞が異常に過敏状態となつて いる状態をい5のである。

陣内教授及びその門下は，このような症攣 準備状態を実験的に動物に附与することがで きないか，できるとすればこの実験的瘁攣準

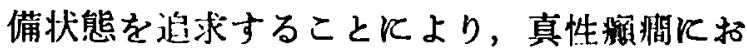
ける特異な瘵攣準備状態を解明するための有 力な键の一つとなるのではないかと考光，一 連の研究を行つた。すなわち神原25), 笠井26) 清水 ${ }^{27}$ )等は卵白, 非働化牛血清及び牛脸灰白 質ホスファチッド加牛血清を動物に皮下注射， 形動脈注射並飞静脈注射等を行い，大杉28)は $\boldsymbol{\alpha}$ 型連鎖状球菌を副鼻胴内より頭蓋内に移行 せしめて, 器質的変化の現われない程度の脸 局所アナフィラキンー（以下脳局「ア」と略 記する）を起さしめることに成功し，これを 潜在性脳局「ア」動物と名付けた。この脳局 「ア」動物について，カルチアン゙ール廰㢣閥

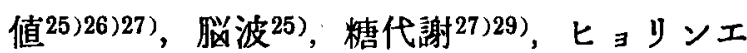
ステラーゼ活性值30)，アミノ窒素31)，神経細

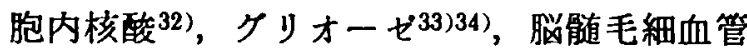

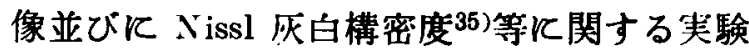
的研究を相次いで行い，これらの成績より替 在性脳局「ア」動物が真性瘼瘤と非常に類似 した痤攣準備状態を附与されていることが明 らかとなつた。

しかし上述の実験は短期間のアレルギー状 態であり，また各々に㽷攣誘発を行つている ことを考え，さらに真性彩間に近い条件を与 える目的で，潜在性脳局「ア」家鬼に括ける
抗原抗体反応を非常に弱い程度のすのとして 数ケ月間反嘌し，その後数ケ月間を無処置に 放置し，しかも痤攣誘発を行はない家鬼を作 り慢性脳局「ア」家鬼と名付けることとした。 すなわち従来の脳局「ア」を慢性脳局「ア」 とした点，抗原抗体反応をごく弱くした点， 痤杽による続発的な变化を除外した点，また 長期の無処置期間を置いて急性アレルギー性 変化の消褪をまつた点に打いて，従来のもの より一層実際に近い条件として実験を行 ここ ととした。

さて痙攣準備状態とは，先にのべたごとく 神経細胞が過敏状態となつていることである。 かかる神経組織の機能に関しては, 電気生理 学的ないし生化学的ことに醇素化学的立場上 り近年広範な研究が行われつつある。ことに 1926 年 Loewi ${ }^{36)}$ が迷走神経素を発見し，つ いで Dale \& Feldberg ${ }^{37), ~ N a c h m a n s o h n ~}{ }^{38)}$ 等が神経末端, 神経線維内の機能が Acetylcholin（以下 Ach と略記する）の作用による と発表して以来, 生化学的研究は急速に発展 を示している.脳 Ach K関しては1936年来 Quastel ${ }^{39)}$ 等飞より脳切片を用5る一連の研 唯が行われていたが，Nachmansohn40)等飞よ り Cholinesterase (以下 $\mathrm{ChE}$ と略記する), Cholinacetylase 等の酥素化学的方法がとり上 げられるよ5になり，以来系統的かつ広範な 研究が進められるようになつた。すなわち Ach は極めて不安定な崩壊しやすい物質で あるが，ChEは安定な物質であり，かつChE 活性値と Ach 形成とは平衡関係にあるため, この安定な $\mathrm{ChE}$ 活性値を測定することによ り神経活動の状態を比較的容易飞推定し るる というのである. Nachmansohn ${ }^{40)}$, 後藤 ${ }^{41)}$, Little ${ }^{42}$ )等は人，犬，象等の脳䯣 $\mathrm{ChE}$ 活性值 をしらべているが，廎㾞患者脳髄に扣ける $\mathrm{ChE}$ 活性値の研究は比較的少いよ5である. 1947 年 $P$ ope $\mathrm{e}^{43}$ 等はいわゆる症候性䫏間患者

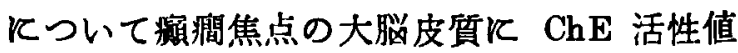
が増加していることを認め，最近沖30)真性 频澗患者飞ても大畄皮質の $\mathrm{ChE}$ 活性值が増 加しており，Ach 代謝が立進していると報告 
している. また沖 ${ }^{30)}$ ，大杉28) は潜在性脳局 「ア」家鬼脳髄の ChE 活性值が增加してい ることを認め，痤攣準偨状態が附与された結 果によると推論している.

私はさきにのべた慢性脳局「ア」家鬼を用 い, 皮質運動領, レンズ核，アンモン角につ いて ChE 活性值を測定し，実験的痤摮準備 状態の一端を追求することにより，ひいては

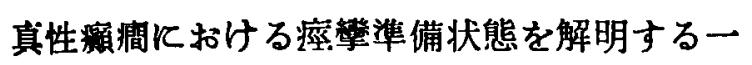
助となるのではないかと考え，本実験を試み た次第である.

\section{第 2 章 実医材料並に実検方法}

第 1 節 実験動物

私は脳算に殆ど器質的变化を認めえない 程度の脳局「ア」を作る目的で, 実験的に脳 局「ア」を起すことが可能であり，しかる他 の動物より起りにくい点, また長期の飼育観 察に便利な点より $2 \mathrm{~kg}$ 前後の白色成熟家鬼を 用いた。

\section{第 2 節 感作抗原の作成法}

牛脳灰白質ホスファチシド加牛血清（以下 牛脳灰「木」加牛血清之略記する) 及び $\alpha$ 型 連鎖状球菌（以下 $\alpha$ 連菌と略記する）の 2 種 を感作抗原として使用した。

a) 牛脳灰「木了加牛血清

牛血清の作成法は, 新鮮な牛血清を数時間 室温飞放置したのち遠沈して血清を分離し， $54^{\circ} \mathrm{C} ， 30$ 分間重擝照にて非働化し $0.5 \%$ の割 合に石炭酸を加えた。

牛脳灰「木」の作成は笠井年), 坂井 ${ }^{33)}$ の方 法に従つた. 即ち新鮮な牛脳の脳軟膜を丁空 飞剩離し，大脳表面の灰白質を乳鉢ててよく 摺磨して泥状とし約 6 倍量の純酒精を加えて 時々膡拌しながら1週間室温飞放置した。こ の上澄を遠沛分離し, 減圧 $40^{\circ} \mathrm{C}$ 飞て酒精を 蒸発せしめると黄褐色の粘稠な残渣を5る. これを少量のエーテルに溶解せしめ, 上澄に 多量のアセトンを加光ると白色沈汼物を作る が，これを反覆し残つた白色沈潵物を褐色瓶 のアセトン液中に貯えた。

b) $\boldsymbol{\alpha}$ 連菌 $\boldsymbol{\alpha}$ 連菌の分離は, Brown ${ }^{45}$ )の分類に従つた。 菌株は大杉28)の使用した菌株と, 細菌学教室 より提供を受けた菌株の 2 種を用いた。肺炎 双球菌との鑑別飞は，形態，家鬼胆汁溶菌試 験, 䕛膜染色試験及びマウスに対する毒力試 験を行い，また腸球菌との鑑別には，エスクリ ーン分解性, 熱仅対する抵抗力試験及び胆汁 反対する態度試験を行い，全く $\boldsymbol{\alpha}$ 連菌の性状 を具備した菌株を鑑別選択して，5\%人脱線 稚素血液寒天に培養保存した。

\section{第3 節 感作方法}

a) 牛脳灰「木」加牛血清感作

アセトン液中の牛畄灰「木」を真空硫酸乾 燥器にて乾燥し， $10 \mathrm{mg}$ を牛血清 $2 \mathrm{cc}$ 飞混合 して原液とした。

感作方法は家鬼耳静脈より pro kg $2 \mathrm{cc} の$ 原液を 2 日間連続注入した. 12 日後に Arthus 反忘を行い陽性の家鬼のみ使用した。

b) $\boldsymbol{\alpha}$ 連茵感作

$\boldsymbol{\alpha}$ 連菌感作には，大杉28)の基礎実験により

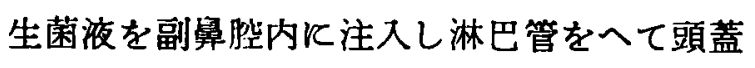
内に逆行せしめるという最も自然で目的に適 した方法をるちいた。

生菌液は分離した菌株より，1\%蒲萄糖加 フイョン（pH7.2 7.4）飞 $37^{\circ} \mathrm{C}, 24$ 洔間培 養し，每分3000回転にて10分間㟫沈し，生理 的食塩水を加えて 2 回遠沈洗滌を反夏したの ち, 脱水, 科量した. これ飞生理的食塩水を 加えて 1cc 中の菌量が $100 \mathrm{mg}$ となるよう に浮遊せしめた。な括一部をフイヨン液に培 養して生菌なることを確めた。

この生菌液を家躳の内㫮より前方 $1.5 \mathrm{~cm} の$ 凹部より,マントウ注射器を用いて上頇洞に 问つて注入した。注入菌量は生茵 $10 \mathrm{mg}$ を隔 日 5 回註入した。

第 4 節 效果注射方法

a) 牛脳灰「木」加牛血清群（以下 P 群と 略記する)

効果注射は感作後14日目に耳静脈より生理 的食塩水による 4 倍稀釈液を pro $\mathrm{kg} 1 \mathrm{cc} の$ 割合に注入し，4 日間隔にて 6 ケ月間注射を 反覆した. その後 1 ケ月及び 3 ケ間を無処 
置に放置したもの（以下 $\mathrm{P}_{1}$ 群， $\mathrm{P}_{3}$ 群と略記 する）を実験材料として使用した。

b） $\alpha$ 連菌群（以下A群と略記する）

効果注射は感作最終日より 3 週間後に副鼻 腔内に行い, 生菌 $10 \mathrm{mg}$ を連日 5 回注入した. その後 1 ケ月間隔にて同一繰作を 4 回行い, 4 ケ月間及び 8 ケ月間を無処置飞放置したも の（以下A 4 群，A8 群と略記する）を実験材 料として使用した。

第 5 節 脳採取方法及び検索部位

脳の採取には, 両側頚動脈より失血致死せ しぬ，死後直ちに開頭して脳䯣を剔出し重曹 抜きリンゲル液にて洗淮し，脳軟脱を丁真に 除去，鋭利な尖刃を用いて皮質運動領，レン ズ核アアンモン角を肉眼的にでき 5 る限り他 部を混入しないよう剔出した。

\section{第 6 節 奏験手技}

Ammon ${ }^{44)}$ 飞做いWarburg 氏娭圧法を用い

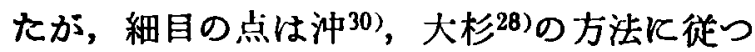

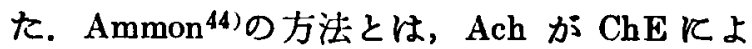
り分解されて放出する醌酸を予め反㤁系に加 えたリンゲル液中の重曹に反忍させ，発生す る $\mathrm{CO}_{2}$ 量を検庄計以て測定し，醳素作用を $\mathrm{CO}_{2}$ 発生量であらわす方法である.

\section{1）組織照濁液}

各種材料を正確に秤量したのち，乳針を用 いて 5 分間よくすりつぶし，リンゲル液にて 皮質運動領は 100 倍，アンモン角は 200 倍, レンズ核は 500 倍の照濁液とし, 各々容器主 室に 2cc 宛入れて用いた。使用するリンゲル 液は実䮖の都慺熘製した。

2）基質溶液

塭化 Ach (Roche) 2.5\% (0.1Mol) の 割合にリンダル液に溶かし, 各々の容器側室 K0.2cc 宛入れて用いた。従つて容器主室の 惩濁液と混和後の主室内全量 $2.2 \mathrm{cc}$ 飞打ける Ach 最終浱度は䄪 $0.015 \mathrm{Mol}$ となる。Ach の自己分解は僅かで修正の要を認めなかつた。

3) 測定条件

容器主室に組織照濁液 2 re を入れ，側室に 基質溶液 $0.2 \mathrm{cc}$ を入れたのち，5\%の割合に $\mathrm{CO}_{2}$ を含む $\mathrm{N}_{2}$ ガスを充分飞通気し，ガス腥
を本混合カスで充填して振嘼装置に連結し た. 恒温槽の温度は $38^{\circ} \mathrm{C}$, 振盪回数は毎分 90 回内外とした．測定は，まず10分間程振盓し 圧が平衡に達したのち，側室の基質溶液を主 室に混入し， 3 分後より読みを開始して10分 毎に值をとり，40分間振盪を続け各々の值よ り計算して $\mathrm{CO}_{2}$ 発生量を求めた。対照とし て同じ基質溶液の同量と惩濁液の代りに同量 のリンゲル液を入れたすのを使用し，同時に 測定して修正を行つた。

\section{第3 章 実 医 成 縝}

以下飞記载する䣼素值は，新鮮脳組織 $100 \mathrm{mg}$ が 30 分間飞発生する $\mathrm{CO}_{2} \mathrm{cmm}$ をる つて表わしたものである。な招実験忓同一 材料につき常に 2 本以上の manometer を使 用して測定し，その平均値をとつた。

第 1 節 正常家鬼群

正常家兔15匹飞招ける $\mathrm{ChE}$ 活性值は，皮 質運動領平均 384，標準偏差土 53.2，アンモ

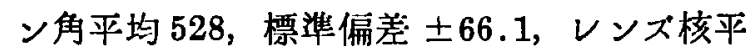
均 3622，標準偏差士255.2であつた。これを 表示すれば第 1 表のごとくである.

第 1 表 正 常 群

\begin{tabular}{r|c|c|c}
\hline \hline & 皮質運動領 & アンモン角 & レンス核 \\
\hline 1 & 415 & 573 & 4035 \\
2 & 427 & 572 & 3433 \\
3 & 430 & 624 & 3584 \\
4 & 419 & 462 & 3937 \\
5 & 345 & 353 & 3864 \\
6 & 407 & 517 & 3770 \\
7 & 232 & 492 & 3910 \\
8 & 291 & 451 & 3735 \\
9 & 425 & 664 & 3435 \\
10 & 441 & 575 & 3270 \\
11 & 367 & 536 & 3624 \\
12 & 392 & 501 & 3826 \\
13 & 395 & 549 & 3203 \\
14 & 404 & 510 & 3295 \\
15 & 381 & 551 & 3412 \\
\hline 承 & 348 & 528 & 3622 \\
\hline 標集偏差 & 53.2 & 66.1 & 255.2 \\
(士) & &
\end{tabular}


第2節 $P$ 群

$P$ 群（P1 群 8 匹， $P_{3}$ 群 7 匹）15匹に扮け る $\mathrm{ChE}$ 活性值は，皮質運動領平均 497 , 標染 差士67.0，アンモン角平均 700, 標準偏差士

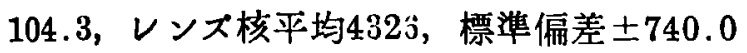
であり，これを表示すれば第 2 表のごとくで ある.

第 2 表 $\quad P \quad$ 群

\begin{tabular}{|c|c|c|c|c|}
\hline & & 皮質運動領 & ンモン角 & レンズ核 \\
\hline 1 & \multirow{7}{*}{$\begin{array}{c}\text { P } 1 \\
\text { 群 }\end{array}$} & 587 & 864 & 3946 \\
\hline 2 & & 593 & 1030 & 5995 \\
\hline 3 & & 590 & 690 & 3132 \\
\hline 4 & & 529 & 627 & 3603 \\
\hline 5 & & 409 & 607 & 3432 \\
\hline 6 & & 515 & 637 & 3482 \\
\hline 7 & & 478 & 659 & 4527 \\
\hline 8 & \multirow{8}{*}{$\begin{array}{c}\text { P 3 } \\
\text { 群 }\end{array}$} & 519 & 733 & 3894 \\
\hline 9 & & 350 & 567 & 5125 \\
\hline 10 & & 414 & 692 & 4648 \\
\hline 11 & & 452 & 631 & 5103 \\
\hline 12 & & 490 & 588 & 4338 \\
\hline 13 & & 494 & 687 & 4247 \\
\hline 14 & & 509 & 708 & 4608 \\
\hline 15 & & 529 & 795 & 4796 \\
\hline 平 & 均 & 497 & 700 & 4326 \\
\hline & \pm & 67.0 & 104.3 & 740.0 \\
\hline
\end{tabular}

第3 節 A 群

$\mathrm{A}$ 群（A4 群 8 匹， $\mathrm{A}_{8}$ 群 7 匹) 15 匹に打け る $\mathrm{ChE}$ 活性値は，皮質運動領平均 466, 祭準 偏差士 46.2, アンモン角平均 689 , 標準偏差 \pm 84.0, レンズ核平均 4103 , 標準偏差 \pm 571 . 3 であり，これを表示すれば第 3 表のごとくで ある.

第 4 節 小 括

1）上記の成績を各タ皮質運動領，アンモ ン角，レンズ核について比帹すること，

皮質運動領； $\quad \mathrm{P}$ 群，A 群共飞正常群飞比 して, 平均値飞抢いて $29 \%, 21 \%$ と明らかに 増加の傾向を示している。これを図示すれば 第1図のごとくである.

アンモン角； P 群， $\Lambda$ 群共に正常群飞比 して，33\%．31\%と明らかに增加の傾向を示
第 3 表 A 群

\begin{tabular}{r|c|c|c|c}
\hline \multicolumn{2}{r|}{} & \multicolumn{2}{c|}{ 皮質運動領 } \\
\hline
\end{tabular}

第 1 図 皮質運動領

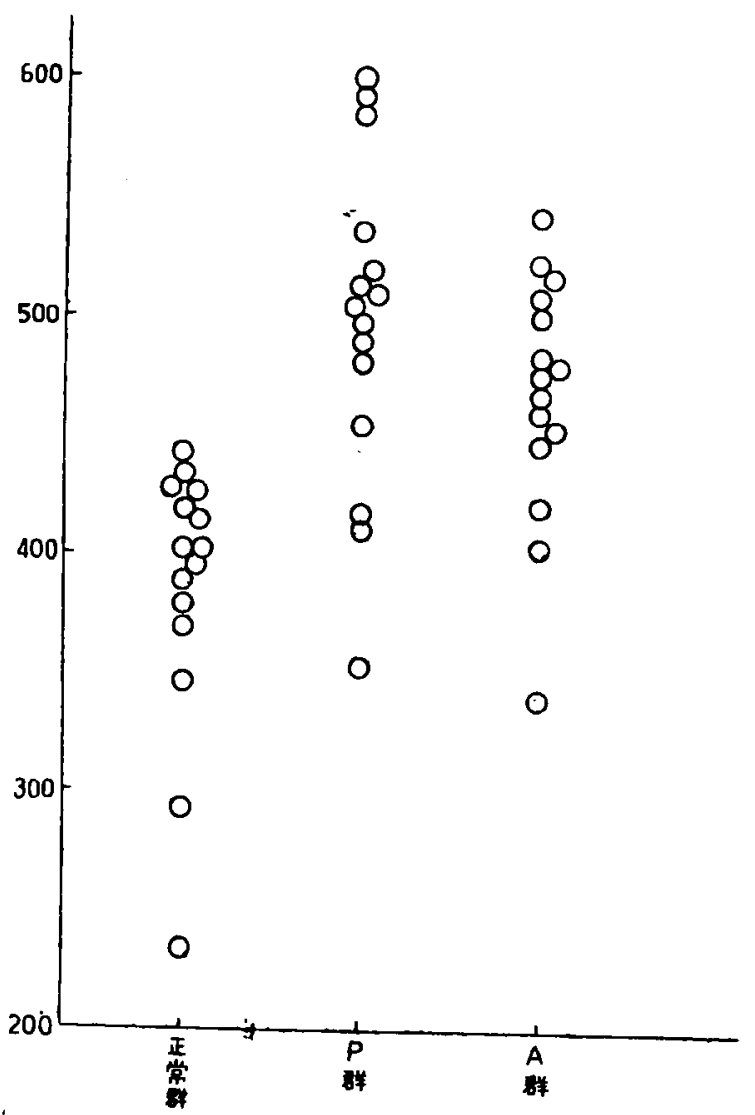

している。これを図示すれば第 2 図の如くで ある。 
第 2 図アンモン角

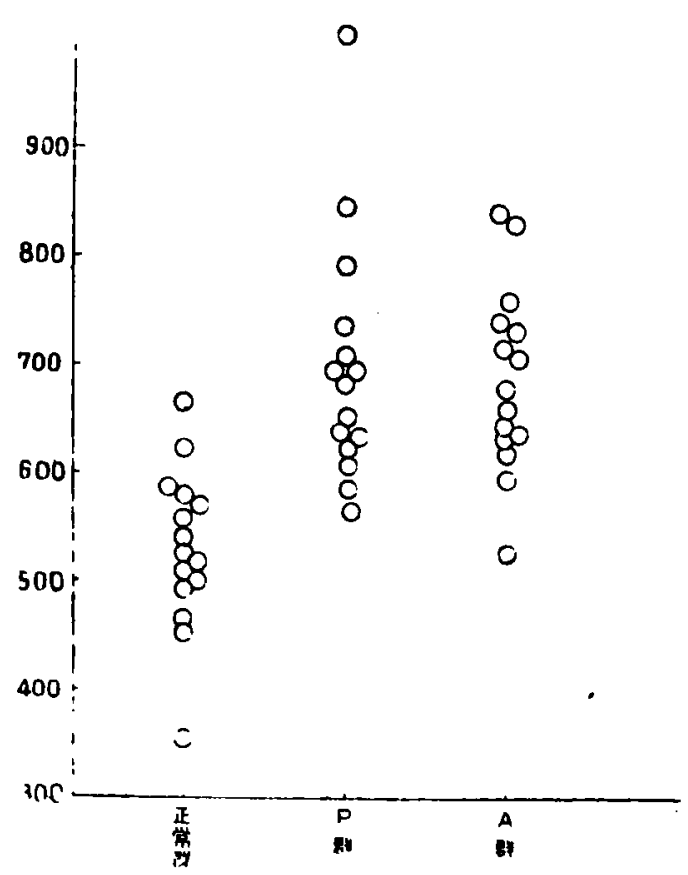

レンズ核； P 群， A 群共に正常群に比し て，19\%，13\%と軽度に增加の傾向を示して いるが，有意の增加とは断定しにくい，これ を図示すれば第 3 図のごとくである.

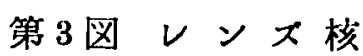

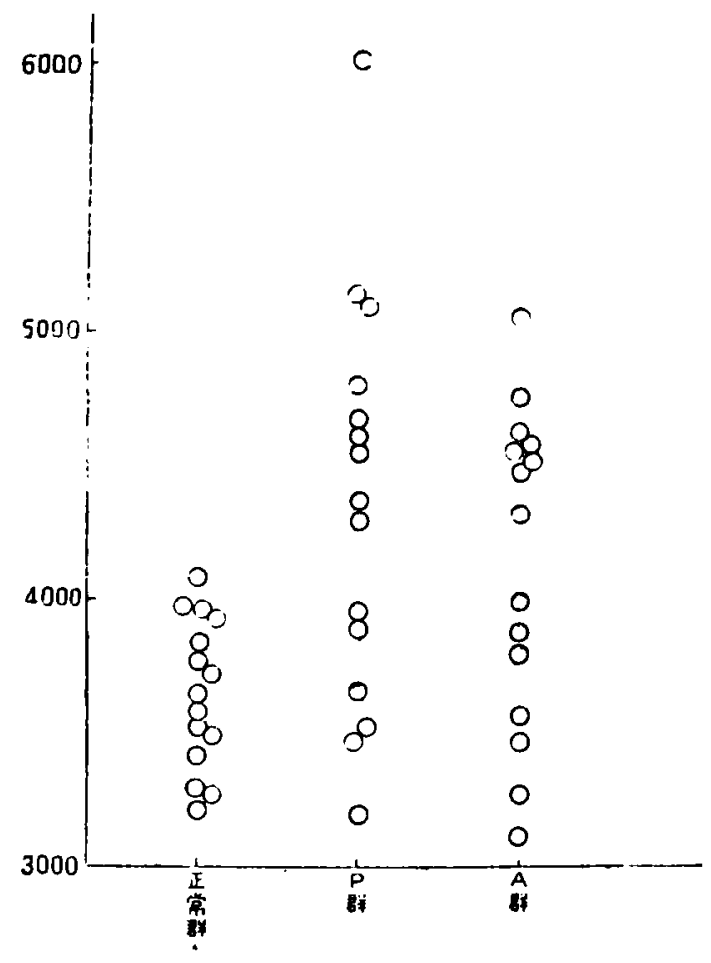

2） $\mathrm{ChE}$ 活性值を効果注射終了後の無処置 期間別に図示すれば，皮質運動領は第 4 図，
第 4 図 皮質運動領（䉆処置期間別）

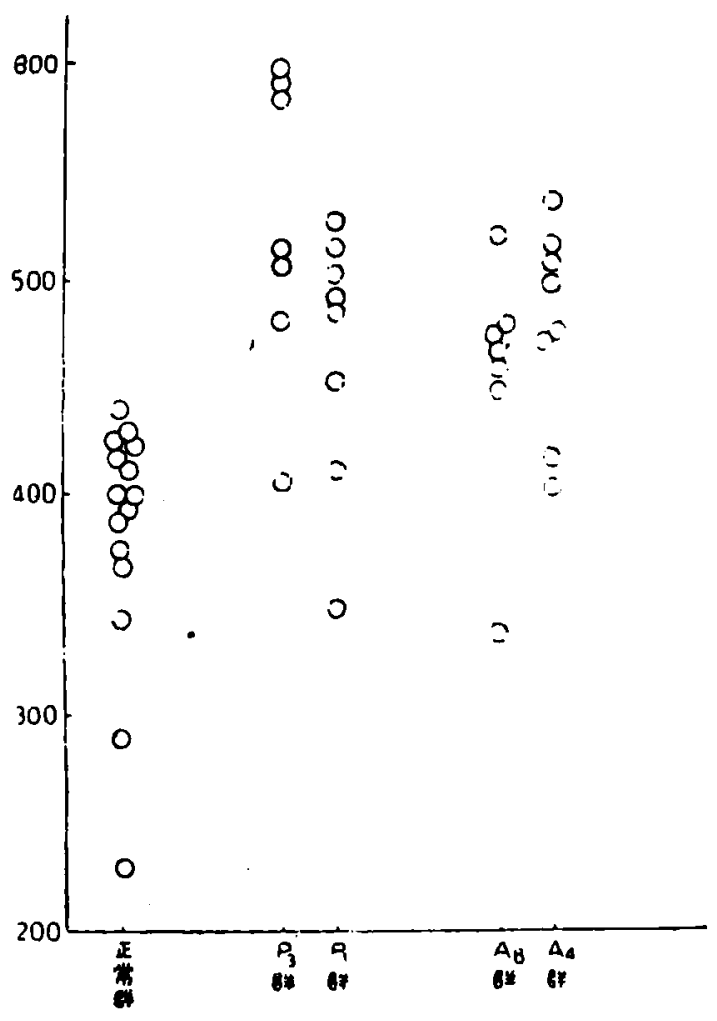

第 5 図 アンモン角（無処置期間別）

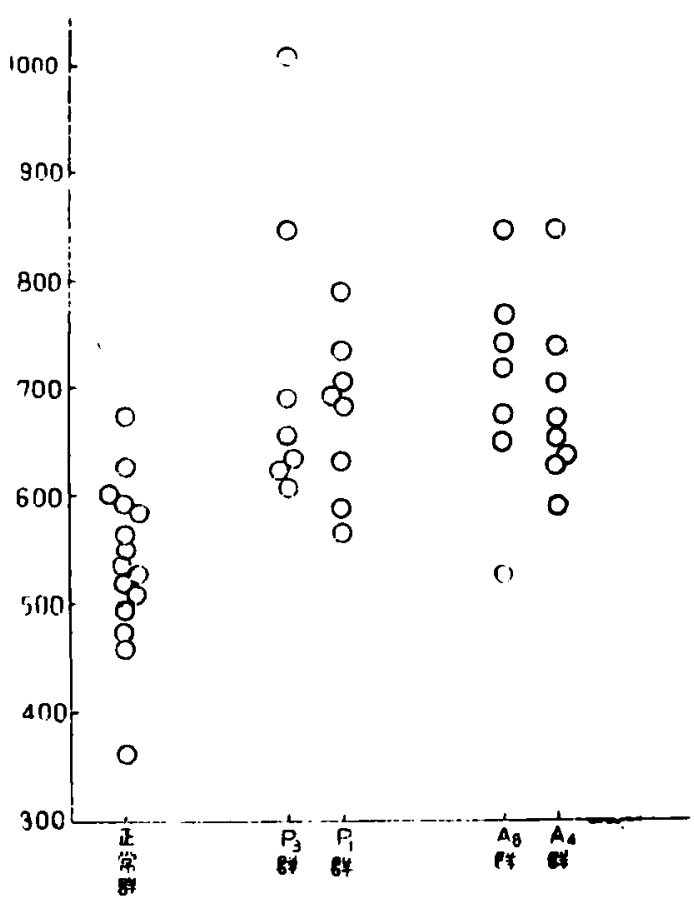

アンモン角は第 5 図, レンズ核は第 6 図のご とくであつて，無処置期間が長期となつても $\mathrm{ChE}$ 活性值は増加したま」で恢復しないも のと思われる。 
慢性脳局所アナフィラキンー家鬼脳艏のヒョリンエステラーゼ活性值……云々

第 6 図 レンズ核（無処置期間別）

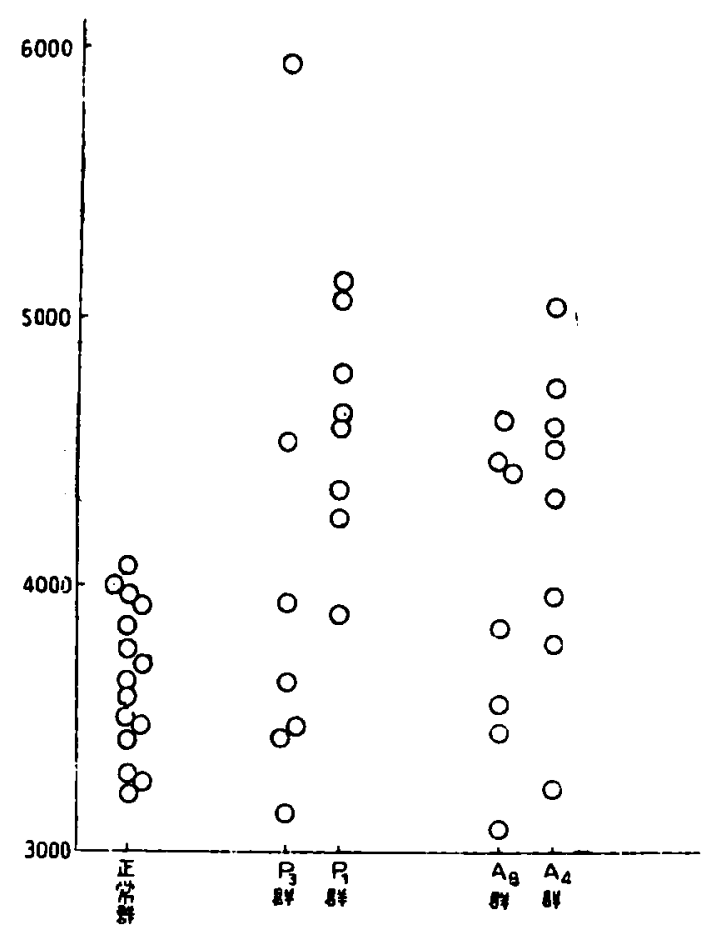

第 4 章 棇括並に考按

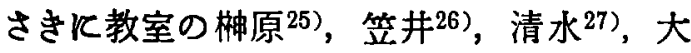
杉 28$)$, 坂井33)等は種々の方法を用いて潜在性 畄局「ア」家鬼を生成し，このるのが真性凝

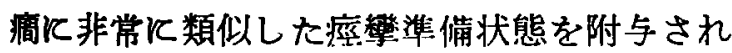
ていることを報告している．私は此較的自然 に近く，かつごく弱い程度の抗原体抗反忘を 6 ケ月間の長期飞互り反復せしめ，症㴚時飞 みられる血管攣縮，断血性変化及び酸素欠乏 性変化を除外するため痤攣誘発を扣こなわず, 急性アレルギー性変化の消祓を待つため1ケ 月から8ケ月間の無処置期間を括くなど，で きる限り続発性変化を避けるよう心掛けて慢 性脳局「ア」家鬼を生成した。 この目的には，

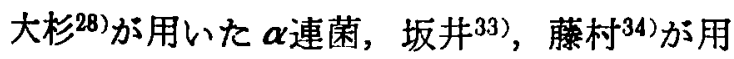
いた牛脳灰「木」加牛血清の 4 倍稀䣋液が最 適していると考え, 各々 A 群, P 群と 2 種 の慢性脳局「ア」家鬼群を生成し，脳解各部 ことに皮質運動領，アンモン角及びレンズ核 の $\mathrm{ChE}$ 活性值を測定比較した。

まず皮質運動領は，痤攣発作の焦点として 古くよりしられている部位であるが，私の実 駼値は，沖30)，大杉28)が脳外套を用いて測定 した ChE 活性值より, 正常群, 実験群共に
各々3096近く高い值を示している. このこと は私の赛験では皮質運動領域のしかる灰白質 のみをとつたためで，同一家鬼においても焦 点と考えられる皮質運動領の ChE 活性值は， 他部大脳皮質又は大脳髄質飞比して一般に高 い值であることがわかる．また慢性脳局「ア」 家鬼群では，P群， $\mathrm{A}$ 群共に正常群に比して 各々 $29 \% ， 21 \%$ と增加を示し，Ach 代謝が立 進していることが認められる.

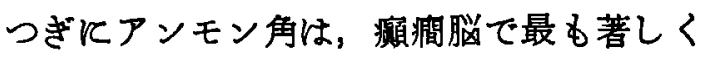
萎縮性硬化像を示す部位とされ，慢性癲瘤患 者の30〜 50 \%にこのよ5な変化がみら れ46)47)48)るとされている. 一方電気生理学的 にも非常に高い反応を示す部位として近年と く飞站目されている．私の実験でもアンモン 角の $\mathrm{ChE}$ 活性值は，皮質運動領の約 1.4 倍 の高值を示している。また慢性脳局「ア」家 鬼群では P 群，A 群共飞正常群飞比して各々 33\%，31\%と著明な增加を認め，Ach 代謝の 異常立進を示している.

レンズ核は，他部より非常高い值を示し， 皮質運動領 $\mathrm{ChE}$ 活性值の 9.4 倍となつてい る.このことは教室の近藤 49 )が犬脳髄各部の $\mathrm{ChE}$ 活性偭を測定し，レンズ核は皮質運動領 の 9.6 倍の高値を認めた事実と一致している.

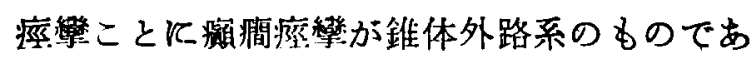
り，かつレンズ㤥と最も密接な関係にあるこ とは幾多の業蹟により明らかとなつている. すなわち林等50)が犬のレンズ核を剔出して観 察した一連の其駼, 教室の近藤 ${ }^{49}$ が犬脳骮通各 部の $\mathrm{ChE}$ 活性值を痤攣各期飞測定して， ンズ核に最も著しい変動を認めた事実また

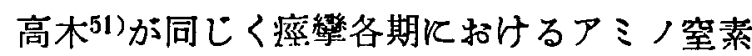
の変動が，レンズ核に最も著明であつたこと など枚挙にいとまがない，私の実験では，慢 性脳局「ア」家鬼群はP群，A群共に19\%， 13\%と軽度であるが増加の傾向を認めた。し かしこの成績で有意の增加と認めることは， 標準偏差，危険率の点より少々むつかしく， 軽度の増加の傾向があるといつた程度に理解 すべきであろう。

このように慢性脳局「ア」家兔の脳髄各部 
飞 ChE 活性值の增加を見たのであるが，元 来 $\mathrm{ChE}$ rは特異性 $\mathrm{ChE}$ と非特異性 $\mathrm{ChE}$ と があるとされ，脳内 $\mathrm{ChE}$ は特異性 $\mathrm{ChE}$ で あるとされ，とくに神経活動飞関与すると考 えられている。すなわち Nachmansohn ${ }^{38) 52)}$ はこの特異的 $\mathrm{ChE}$ 活性值の增加することは Ach 代謝が盛なことであり，神経機能の六進 を意味するるのであるとしている．一般に中 枢神経系における神経機能はいまだ不明の点 が多く，吾々は僅かにその一端をらかがい知 るにすぎない，上記の Nachmansohn ${ }^{38 / の}$ の説 も色々と批判を浴びてきたのであるが，最近 では脳内 Ach の役割は衝撃因子そのるのと 考学るより, 衝揧伝導の助長, 促進因子と して理解されている。また最近に括いて，豊 田53)等は脳内 $\mathrm{ChE}$ を組織化学的に検索し,

灰由質内の極めて緎細な神経線維中に ChE の存在することを認め，雓体路をはじめその 他の有髄神経系内にる検出しているが，この ことは中枢神経系の $\mathrm{ChE}$ K関して新しい示 唆を与えてくれるものと考学られる.

癭間患者脳䯣の $\mathrm{ChE}$ 活性值飞関する報告 は極めて少いが，Pope ${ }^{43)}$ は䁰間焦点の大脳 皮質飞括ける $\mathrm{ChE}$ 活性值か，焦点以外の大 脳皮質及び正常大脳皮質の $\mathrm{ChE}$ 活性値に比 して一般に増加して括り，教室の沖 ${ }^{30}$ ) 真性 頻閪患者の大脳皮質の $\mathrm{ChE}$ 活性值が正常 人脳皮質飞比して増加していることを認 め, Ach 代謝が元進していると推論してい

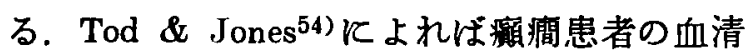
$\mathrm{Ch} \mathrm{E}$ 活性值は正常人に比して低值であり, Schütz ${ }^{55}$ ) は血清 ChE 活性值の低い程発作発 生頻度が增すといつている.また沖中, 吉川豆) は癲痐患者では脳脊髄液中の $\mathrm{ChE}$ 活性值が 減少していることを報告している。しかし先 そのベたごとく，血清，脳背䯣液 中の $\mathrm{ChE}$ は非特異性 $\mathrm{ChE}$ であつて，脳内に括ける特 異的 $\mathrm{ChE}$ との関係は現在な括確然としない 点が多いのであるが，癩眮患者脳髄において $\mathrm{ChE}$ 活性值が正常脳髄飞比して異常状態とな つていることは容易に考えられるのである.

また潜在性脳局「ア」家兔脸䯣の $\mathrm{ChE}$ 活
性值化関しては，救室の沖 ${ }^{30)}$ が卯白，牛血清 及び牛脳灰「木」加牛血清をもちいて生成し たすのについて, 脳外篹の $\mathrm{ChE}$ 活性值が著 明に增加することを認め，大杉28)は $\alpha$ 連菌 をもちいて生成したものとついて測定し，同 様の増加を認めている．すなわち潜在性脳局 「ア」状態により，永続するカルシアゾール

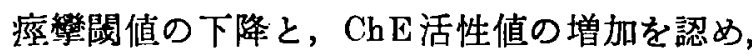
痙卛準備状態附与に上ると推諭している。

私の実験飞扔いても，抗原の種類及び感作 方法の異る $\mathrm{P}$ 群， A 群共に正常群に比してほ ぼ同程度の $\mathrm{ChE}$ 活性值の増加を認めたこと は，あきらかに慢性脳局「ア」によるるので あり，さらに無処置期間が長期となつてす $\mathrm{ChE}$ 活性值の増加が変動してこないことより, 比較的永続性と括るわれる脳神経細胞過敏状 態として固定されたのではないかと考劣られ る.

すなわち，非常飞弱い抗原抗体反応を長期 間反覆せしめることにより，家鬼脸韨永続 的な瘵攣㳣俑状態を附与しうるのである。

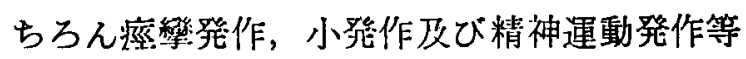
々複雑な症状群である頻痱の本態を, 痤攣発 作のみしか目標となしえない動物実験をるつ

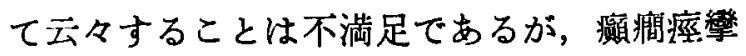
準借状態を奏験的に動物に附与世しめ，これ を詳細に追求することにより真性䫏痱におけ る特異な脳内代謝を解明する鍵とすることは 意義あることと考える次第である。

\section{第 5 章 結 論}

牛脳灰「木」加牛血清 4 倍稀釈液を静脈内 に注入する方法と， $\alpha$ 連菌を副鼻院内に注入 する方法とをるちいて 6 ケ月間抗原抗体反心 を反覆せしめ, 1 ケ以上 8 月間を無処置飞 放置した慢性畄局「ア」家鬼を生成し，各々皮 質運動領，アンモン角及びレンズ核の ChE 活性值を測定比較して，つぎの所見をえた。

1）家鬼脸髄各部の $\mathrm{ChE}$ 活性值は，皮質 運動領，アンモン角及びレンズ核の順に高い 値をえた。

2）慢性脳局「ア」家鬼群と括いては，皮 
質運動領及びアンモン角の $\mathrm{ChE}$ 活性值が正 常群飞比して著明な增加を示し，レンズ核で は軽度な增加の傾向を認めた。

3）各部に打ける $\mathrm{ChE}$ 活性值の增加は, 長期間放置しても変動を認めなかつた.

4）各部における $\mathrm{ChE}$ 活性值の增加は, 感作抗原の種類及び感作方法が異っても差異 を認めなかつた。

5）すなわち非常に弱い抗原抗体反忍を長

\section{文}

1) Horsley：斉藤 真：脳と神経，1；150(1948) より引用.

2) Conrad 諏訪 望：精神々経学誌４3；286 (1939) より引用.

3) Pierre Marie Zbl.'Neur. 50 ; 247 (1928)

4) Claude, Mareel \& Paul. Zbl. Neur. 76 ; 474 (1935)

5) Förster \& Spielmeyer * Z. Neur. 148; 285 (1933)

6) Fischer \& Thurzo: Zbl. Neur. 43; 707 (1926)

7) Bigwood Zbl. Neur. 38 ; 470 (1924)

8) Speransky Arch. Neur. (Am. ), 27, 525 (1927)

9) Ely Arch. Neur. (Am.), 24,943 (1930)

10) Stiefler. Dtsch. Z. Nervenhk., $81 ; 110$ (1924)

11）中村正已：臨床医報， $1 ； 8$ (1947)

12) Spangler J. Lab. \& clin. Med., (Am.), $13 ; 41$ (1928)

13) Ball Am. J. Med. Sci., 173 ; 781 (1927)

14) Ward \& Patterson : Arch. Neur. (Am.), 17 ; 427 (1927)

15) Wallis, Nicol \& Craig: Lancet, 1 ; 741(1923)

16) Forman : Arch. Neur. (Am.), 32 ; 517 (1934)

17) Dattner : Z. Neur., 111 ; 632 (1927)

18) Levin: J. Amer. med. Assoc. 97 ; 1624(1931)

19) Kauders : Wien. Klin. Wschr. 48 ; 109 (1936)

20) Kennedy : Arch. Neur. (Am.), $15 ; 28$ (1926)

21) Pagniez \& Lievtaud Press. med. 27,693 (1919)

22) Kennedy : Arch. Neur. (Am.), 9 ; 557 (1923)

23) Rosenow Postgrad. Med. 2 ; 346 (1947) . ditto 3 ; 367 (1948)
期間反罂せしめることにより，家鬼脳戨各部 飞永続的な $\mathrm{ChE}$ 活性値の增加を認め, 脳神 経代謝が異常に立進していることを知つた。

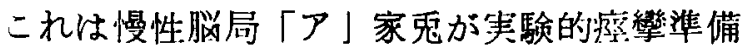
状態を附与ざれたためであると考えられる。

擱筆するにあたり，終始御愁篗なる御指導と御校 閲を賜つた恩師陣内教授に謝意を捧げ，併せて $\alpha$ 型 連銷快球菌怢の呈供を賜つた細菌学敨室に深甚の謝 志を表す。

献

24) Bering J. Neurol. Neurosurg. a. Psy. (Brit), $14 ; 205$ (1951)

25）唧原 农：岡山医学会猚誌，64；347 (1952)

26）筑井蹃藏：岡山医学会雑誌，64，1587（1952）

27）清水整也. 岡山医学会雑誌, $65 ； 43$ (1953)

28）大杉 実：岡山医学会雑誌，65；1411 (1953)

29）兼松武焳：岡山医学会雑志，65；1271 (1953)

30）沖 修之 . 岡山医学会雑誌，64；（1952）

31）井上满：岡山医学会雑誌，64；8，1637(1952)

32）立花春夫：岡山医学会䧴誌，65；1361 (1953)

33）坂非扼典：第11回日本兴神経外科学会に発表。

34) 藤村显治：第14回日本脳神経外科学会飞発表.

'35) 西本 詮：岡山医学会雑誌，65，1127 (1953)

36) Loewi : Pflügers Arch. f. gesamt. Physiol., $189 ; 239$ (1921) ditto $214 ; 678$ (1926)

37) Dale, Felderg \& Vogt: J. Physiol., 86 ; 353 (1936)

38) Nachmansohn: Bull. Soc. Chem. Biol. Paris, $21 ; 1761$ (1939)

39) Quastel, Tennenbaum \& Wheathy : Biochem. J., $30 ; 1668$ (1936)

40) Bullock \& Nachmansohn ; J. Neurophysiol. , $9 ; 253$ (1936)

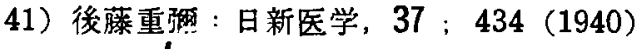

42) Little ; Am. J. Physiol., 155 ; 60 (1948)

43) Pope: Reserch Nervous mental Disease, 26 ; 218 (1947)

44) Ammon Pflügers Arch., 233 ; 486 (1934)

45) Brown : Principles of 'Bact. \& Timnm., 434.

46) Sonumer：下田：神経学雑誌, 27 ; 535 (1927) より引用,

47) Alzheimer. Allg. Z. Psychiatr., 53 ; 418 (1907) 
48) Uchimura Z. Neur., $112 ; 1$ (1928) ditto $114 ; 567$ (1928)

49）近藤儤二：岡山医学会雜誌，65，139 (1953)

50) 林 鳞: The Japanese Journal of Physio$\log y, 3 ; 46$ (1952)

51）高木秀婎：岡山医学会雑誌，65；1113 (1953)

52) Nachmansohn : J. Neurophysiol., 1; 11 (1947)

53）豊田正：日新医学，42；302 (1955)

54) Tod \& Jonee : Quart. J. Med., 6 ; 1 (1937)

55) Schütz: J. physiol., 102 ; 369 (1943)

56）冲中，吉川：医学と生物学，25；10(1952)

Dept. of. Surgery, Okayama University Medical School

(Director : Prof. Dr. D. Jinnai)

On the Cholinesterase activity, free aminonitrogen and

ketoenolic granuli in nerve cells in chronic cerebral local anaphylactic rabbits.

Part I. On activity of cholinesterase in rabbits brain with chronic cerebral local anaphylaxis.

By

Tetsuro HATAYAMA

An antigen-antibooy reaction was repeated for 6 months long by intravenous injection of 4 times diluted cow serum with phosphatide and by injection of $\alpha$-streptococei in paranasal ravity of rabbits. They were let free from any procedure for more than 1 month to 8 months. Thus the chronic cerebral local anaphylactic rabbits were made. The Ch-E activity in each motor cortex, Ammon's horn and nucleus lenticularis was measured. The results were as follows:

1) Ch-E acitivty in each rabbit's brain was ranged in the order of the motor cortex (highest), Ammon's horn and then nucleus lenticularis.

2) In the chronic cerebral anaphylactic rabitbs, Ch-E activity in the motor cortex and Ammon's horn was much higher than that of normal one, and in the nucleus lenticularis it trulled to increase slightly.

3) The increase of Ch-E activity in each part showed no fluctuation even during long time without any management.

4.) The increase of $\mathrm{Ch}-\mathbf{E}$ activity in each part was not influenced by the kinds of sensitizing antigen or of the methods of sensitization.

5) The permanent increase of $\mathrm{Ch}-\mathbf{E}$ activity and abnormal accelaeration of brain metabolism in ral,hits brains were observed by the repeated reactions as above-stated for a long time It would appear that, the chronic cerebral local anaphylactic rabbits were given an experimental epileptic arrangement. 